\title{
From Shorty Blake to Tubby Binns: Dunkirk and the Representation of Working-Class Masculinity in Postwar British Cinema
}

\author{
Gill Plain
}

\begin{abstract}
We must really decide whether we are telling a human story against the background of a military campaign, or whether we are telling the story of that campaign itself. The present treatment simply postpones that decision, because it gives us both sides of the story at such length that it would make two entire movies. ${ }^{1}$
\end{abstract}

I must reiterate that the major disappointment is in the characterisations, both civilians and soldiers. ${ }^{2}$

This article asks the question: what went wrong with Dunkirk (1958)? Why isn't this ambitious film remembered as the pinnacle of Ealing's achievement and a fitting memorial to an event which has become integral to mythologies of the British nation? The production did not lack resources. Backed by a new joint production arrangement with MGM, the film was closely superintended by Michael Balcon, who confessed in a letter to screenwriter David Divine that he had 'a passion for the subject'. ${ }^{3}$ The film enjoyed the full cooperation of Army and Admiralty, and was cast with familiar faces capable themselves of attracting an audience. Yet Dunkirk received only a lukewarm critical reception and has, since its release, attracted the bare minimum of critical attention. ${ }^{4}$ The reasons for this somewhat bathetic end to an enormous project are manifold. Balcon was obliged to navigate his embryonic film product through a range of pre-production crises including the breakdown of relations with the initial scriptwriter, R. C. Sherriff, the threat of legal action surrounding versions of the story

Journal of British Cinema and Television 9.2 (2012): 177-197

DOI: $10.3366 /$ jbctv.2012.0078

(C) Edinburgh University Press

www.eupjournals.com/jbctv 


\section{Gill Plain}

and screenplay, the prospect of competing films and the failure to secure Jack Hawkins in a central role. ${ }^{5}$ Yet, as Kenneth Tynan's memo suggests, the film's problems were also structural: its epic intentions burdened it with representational obligations almost impossible to satisfy. Military campaigns are not easy to depict on screen, and ambitions to 'tell the truth and nothing but the truth' do not sit easily with the demands of effective story telling. ${ }^{6}$ Indeed, the film in conception should be seen as two films: an original, less ambitious project, devised under the working title The Big Pick-Up, and the later Dunkirk, which placed this story within a much larger, self-consciously historical, framework.

The conflict between epic and intimacy was one problem. Another was the relative historical proximity of the Dunkirk evacuation. Many of the military personnel depicted in the film were still alive; others had family understandably concerned about the dangers of posthumous misrepresentation. Archival correspondence makes it clear that everybody, from the Dunkirk Veterans Association to the French Navy, felt they had a vested interest in the film, and although Balcon and Associate Producer Michael Forlong worked hard to reassure all concerned, the film's release nonetheless generated a heated debate about the authenticity of its representations. Responding to the controversy in a letter to The Times a month after the film's premiere, Balcon and director Leslie Norman concluded that: 'Three hundred and thirty-eight thousand had stories to tell and we had but two and a quarter hours in which to translate some of them to the screen. ${ }^{7}$ In spite of this disclaimer, the film strives for maximum inclusivity at the same time as it treads with extreme care in the depiction of the armed forces, criticising policy 'back home' rather than military actions or decisions. This element of dutiful memorialising is perhaps what prompts Charles Barr to describe the film as 'very dull indeed' (1998: 179):

How right that Ealing at the end of its span should look back to the event which in effect had made it what it was: to Dunkirk, the turningpoint of the war, the transforming event which we look back on in the same wistful spirit with which we look back on the classic Ealing films themselves... The film shows a dispirited, sluggish country blundering its way to disaster - a picture consistent with the films Ealing was making in those years. (Ibid.)

As this analysis suggests, the film's relationship to both historical and cinematic past is complex, but it is also fraught with difficulty arising from the broader context of its production. Beyond all the 
technical issues encountered in its planning, Dunkirk is permeated with tensions that speak as much to the cultural changes and class anxieties of the mid-1950s as they do to the 1940 evacuation of the British Expeditionary Force (BEF) from France.

Dunkirk's attempt at neutral historicising disguises a notinconsiderable nostalgia, most clearly evident in its attempt to reconstruct the 'group hero' characteristic of Second World War cinema. As I will demonstrate by a comparison with an early example of the group-hero narrative, Noel Coward's In Which We Serve (1942), Dunkirk struggles with the effective presentation of both the group and the working-class men who comprise it. While this is, in part, the product of scripting issues which seem never to have been resolved, it also speaks to the impossibility of historical verisimilitude and the inevitable instability of repetition. While the film attempts to embrace all possible dimensions of the campaign and its human stories, it can only do so from the perspective of 1956-7, the years of planning and production. Its group hero is, therefore, not that which emerged in the cinema of the critical war years 1940-3, but rather a version shaped by what Neil Rattigan has described as 'the last gasp of the middle class' (1994: 143).

The years between Dunkirk as event and Dunkirk as cinema were, in terms of both class and nation, complicated by a rear-guard action fought by a once secure but now somewhat beleaguered establishment. Ross McKibbin has suggested that the Second World War regenerated a traditional working class eviscerated by the economic and political failures of the $1920 \mathrm{~s}$ and, in so doing, weakened the 'modern' middle class whose outlook had predominantly shaped the 1930s. By 1951 this had resulted in the paradox of a society characterised by previously unthinkable social welfare reforms built upon fundamentally unchanged institutional structures (1998: 528-36). ${ }^{8}$ McKibbin concludes that this was a balance which could not hold, and indeed, a decade later, the politics of Britain, its international status, its society, its culture and its cinema would all have undergone far-reaching and radical change. Perhaps the most obvious benchmarks of transition were the humiliation of the Suez Crisis in 1956 and the emergence of the 'angry young man' as embodied in John Osborne's Jimmy Porter in Look Back in Anger, which opened at London's Royal Court Theatre in May that year. It is events such as these, simultaneously encoding an international loss of status and a domestic loss of stability within established middle-class structures of deference, which lead Neil Rattigan to posit a middle-class backlash. Arguing that it was no longer necessary for film-makers to 'foster 
notions ... of social and cultural solidarity in order to unite the country to meet the demands of a people's war' (1994: 148), he suggests that cinema gradually saw 'the people' replaced by the middle classes in a 'last ditch effort by the dominant class to maintain its hegemony by rewriting the history of the celluloid war in its own favour and offering this as a remembrance of the way things were' (ibid.: 150). War films were the pre-eminent genre of the decade, and although they depicted the so called 'people's war', more often than not, argues Rattigan, they were fundamentally concerned with putting the 'people' back in their place. And somehow, in spite of having a major star in a central working-class role, Dunkirk manages to do exactly that.

The star in question was John Mills, who had been linked to the project from its initial conception as The Big Pick-Up, and the film is in many respects typical of the wartime narratives in which he excelled. Dunkirk is an ensemble drama in which three characters together represent a snapshot of the nation. Mills is the chirpy working-class soldier, Corporal Tubby Binns, stationed in France as part of the BEF. Richard Attenborough is Mr Holden, henpecked husband, new father and complacent incumbent of a reserved occupation: a character who cannot see beyond his own backyard. Finally, there is Bernard Lee as Charles Foreman, a journalist who becomes increasingly sceptical about the management of the war. Foreman is the film's educated middle-class mouthpiece. He sets the moral tone, points out the failures of communication and strategy-reminding the audience of the mistakes of appeasement-and, as the film progresses, emerges as the leader of the civilian war effort. These three characters are each pulled into the drama of Dunkirk and will eventually meet on the beach in what is arguably the crux of the narrative. For Mills' and Attenborough's characters, there is a journey to be undertaken. Tubby, reluctantly left in charge by the death of his officer, must lead his motley platoon through the advancing German lines to 'safety' on the beaches. Mr Holden must throw off the shackles of domesticity, abandon his political blinkers, rediscover his masculinity and sail his small boat to Dunkirk. Mr Foreman, who is already all-seeing and adequately masculine, must also sail to Dunkirk-but not for the purpose of personal development. Rather he sets an example for the reluctant Holden and, on arrival, educates Tubby on the subject of international politics before being shot by a passing Stuka. Tubby and Holden live to fight another day, but the conclusions of their stories are also profoundly gender and class normative. Holden's flagging masculinity is restored by his actions and through mistaken identity when, on returning to England, he is inadvertently interpellated as 
a soldier. The emasculating effect of his wife has been counteracted through appropriately masculine agency. And finally Tubby, after his brief outing as a leader of men, is shown restored to his appropriate class position, square-bashing with the rank and file.

Arguably there are two group heroes in Dunkirk; the one comprised of the roles filled by the star performers, John Mills, Richard Attenborough and Bernard Lee; the other, a more conventional military group made up of the platoon struggling to find its way back to the beaches. The first group is designed to be symbolic: three different types of men, living radically different lives, bring contrasting perspectives to bear on the monumental historical event of the evacuation. The cross-class constitution of this group stands in marked contrast to the wholly working-class contingent comprising the second group. The typical group hero of early-1940s narrative incorporated class, regional and temperamental diversity, and neither of Dunkirk's two groups conforms neatly to this template. In the case of the first group, the characters' symbolic function dominates; they come together only towards the close of the film and have little opportunity to bond. For the second group, the problem is one of homogeneity: the characters making up the platoon are indistinguishable. Yet both groups attempt to recreate aspects of the original group hero function: they represent ordinary people working together to achieve extraordinary things, and they aim to give the spectator recognisable figures with whom to identify in the otherwise overwhelming historical narrative.

The difficulty of constructing a viable group hero in the context of Dunkirk's monumental memorialising is evident in pre-production debates about the screenplay. Kenneth Tynan complained about a lack of effective characterisation as early as February 1956, and Leslie Norman's notes on Sherriff's screenplay reiterate this point. David Divine's assumption of screenwriting duties did not solve the problem, and in September 1956 Michael Forlong is concerned that the script fails to generate an interest in the three soldiers Binns, Bellman and Mike. ${ }^{9}$ Balcon shares this reservation, noting in January 1957 that the relationships sustaining the group of soldiers in the original draft of The Big Pick-Up have been lost, with the result that the 'death of Bellman... does not involve us emotionally because we know so little about him'. ${ }^{10}$ These problems were not resolved, and in the final product only Tubby Binns and his sidekick Mike emerge as recognisable characters. While Tubby's adventures might be regarded as a democratic resurgence of the individual working-class hero, I will argue that in fact both the role of Binns and the casting of John Mills 


\section{Gill Plain}

work against any such outcome. Focusing on the meanings encoded by the actor as a 'cumulative cultural product' (Plain 2006: 9), I will suggest that in the casting of John Mills, the film-makers were not recreating the group hero of the 1940s but, rather, were burdening their film with a star whose mode of working-class performance had come to have comic rather than heroic connotations. ${ }^{11}$ Tubby Binns, as embodied by the 50-year-old John Mills, cannot be the modern working-class hero about to emerge as part of the British New Wave, but neither can he re-inhabit the once-radical workingclass masculinity of his performances in the 1940s. Instead, Mills' presence on the screen adds a further layer of complexity to an already contradictory and underwritten role. Exploring Tubby Binns thus provides insight into the tensions at the heart of Dunkirk, a film which, in both generic structure and performance convention, does not know the story it is telling.

\section{Exemplary national narratives: looking back to In Which We Serve}

The problems surrounding working-class representation in Dunkirk come more clearly into focus through comparison with the 1940s group hero ideal. Although In Which We Serve (1942) was not an Ealing product, it was an early and important manifestation of a group hero narrative, and it shares remarkable similarities in theme, structure and personnel with the later Dunkirk. Both films tell a story of the underdog's triumph over adversity, both work through a tripartite structure offering three focalisers or points of identification, and both deploy John Mills as the embodiment of plucky working-class masculinity. Furthermore, placed as they are at the beginning and end of what can be seen as a period of class uncertainty and renegotiation, both films attempt to represent the nation in all its diversity.

Like Dunkirk, In Which We Serve tells a story of defeat, in this case the sinking of a ship. HMS Torrin is lost in the Battle of Crete, but this is just a beginning for the film as through flashback and character development Noël Coward recasts events in such a way as to snatch victory from the jaws of defeat. Catastrophe becomes an opportunity for the manifestation of British character, and British character the basis for national self-belief. Ironically, at the time of In Which We Serve's production, this mythologising process had already been enacted in relation to the historical events of 26 May-3 June 1940. J. B. Priestley's Postscript radio talk of 2 June 1940 cast the 
evacuation as the triumph of the underdog and the moment when circumstances turned civilians into a fighting force:

This little steamer, like all her brave and battered sisters, is immortal. She'll go sailing proudly down the years in the epic of Dunkirk. And our great grand-children, when they learn how we began this War by snatching glory out of defeat, and then swept on to victory, may also learn how the little holiday steamers made an excursion to hell and came back glorious. (1940: 4)

This rhetoric, and the narrative dynamic which it encodes, is echoed by In Which We Serve and Dunkirk, both of which end with rousing voiceover commentaries which confirm and endorse a national purpose. However, there is a difference in emphasis between the two. While In Which We Serve offers a paean to British ships and the men who sail in them, Dunkirk seems intent on a discourse of self-improvement: 'Dunkirk was a great defeat and a great miracle. It proved-if it proved anything - that we were alone, but undivided. No longer were there fighting men and civilians. There were only people: a nation had been made whole.' But there is something unsettling, or faintly disturbing, about the combination of 'a great defeat and a great miracle', particularly in the post-Suez context of the film's production. The statement verges on the sadistic, rather like suggesting that there is nothing like a good beating to make the child see sense, and the implication is that Dunkirk woke up the nation in much the same way. This difference in tone indicates the limits of comparison between the two films. Coward's film was made in 1942 and, as Jeffrey Richards has observed, it was 'essentially a film about the present' (Aldgate and Richards 1994: 211). Norman's Dunkirk, by contrast, has the benefit of hindsight - and this largely accounts for the latter film's tendency to lecture. Another contrast is suggested by the obviously deferential tone of In Which We Serve - but as Richards' perceptive analysis notes, this deference is complex. The film is both 'a resounding endorsement of the existing class system', and 'the first film to give equal screen time to the other ranks' (ibid.: 208). Consequently, however we might read it now, at the time of its production In Which We Serve was an immensely successful and popular depiction of national cross-class cooperation that broke new ground in its representation of the working classes on screen. A good example of this is provided by the flashback to Shorty Blake's archetypal working-class wedding day, a short sequence which seems designed to promote and develop the concept of the British class system as a family structure. The raucous, cheerful wedding montage is presided over by the figure of the weeping mother, but it is Blake's 


\section{Gill Plain}

commanding officer who will provide a more appropriate paternal blessing for the union. The honeymooners are on their way to Torquay, embracing in their railway carriage, when they are interrupted by the opening door, which reveals Captain Kinross (Noël Coward) and his wife (Celia Johnson). Embarrassment gives way to congratulations, and the encounter shows both the comfortableness of the classes with each other (the sense of 'family' is reinforced by the revelation in the following scene that that the Kinrosses also had their honeymoon in Torquay), and an ongoing, unquestioned hierarchy. Although the scene is typically deferential-Shorty leaps to attention - it also suggests the vitality of the young couple, who combine a realistic knowledge of what the future holds with a capacity to joke and have fun. They are shown enjoying themselves, but apart from Mills' horrified face when Kinross appears, they are not themselves comic. As I will illustrate later, the same cannot be said of Dunkirk.

The contrasting depictions of class relations in the two films also has wider repercussions. In Which We Serve used three characters serving together on a ship in order to mobilise concepts of family and nation. There was no need for political lectures - these characters were united by a shared purpose and a clear understanding of their roles within both the ship and the body politic. Their families, in turn, are depicted as sites of emotional sustenance which are subordinate to the ship but in harmony with its ideals. Dunkirk, by contrast, suggests an absence of shared purpose. Although all three characters behave heroically, for two of them this is the end-point of the narrative rather than an underlying certainty, and when family structures are depicted, they are shown to be at odds with, or even undermining, the national need. Given the film's commitment to the memorialisation of communal effort, this fundamental challenge to its own mythology might seem somewhat dissonant. However, there are a number of possible explanations. Arguably, the presentation of home-front dissent might be seen to reinforce the film's realist credentials, but a more likely explanation lies in the radical revision of women's roles and gender expectations in the years since the end of the war. As will be discussed later, it is specifically women (and a single emasculated man) who do not understand the war and its demands. It was now no longer necessary to depict women's strengths as part of a propaganda drive to convince women of their investment in war and the national community, and the female characters of Dunkirk thus conform to the largely domestic and deadly stereotypes prevalent within 1950s film-making.

The uncanny sense of duplication between the two films is intensified by the personnel involved. Aside from the reappearance 
of John Mills, both films also give a significant role to Richard Attenborough, who made his screen debut in In Which We Serve, playing the stoker who panics under fire, and who, by the time of Dunkirk, had come to specialise in playing shifty, unreliable cowards. His appearance as the henpecked Holden is thus a piece of typecasting which parallels Mills' appearance as the plucky British soldier. Dunkirk is the third pairing of Mills and Attenborough as hero and coward - the second being Roy Ward Baker's submarine drama Morning Departure (1950)-which suggests that, as far as the performative dimension of the film was concerned, Michael Balcon and Leslie Norman were looking for tried and tested commodities, for continuity rather than change. These patterns of casting are important for understanding the construction of the film text. As Barry King argues, the actor 'as a member of the host culture-with a given hair colour, body shape, repertoire of gestures, registers of speech, accent, dialect and so on-always pre-signifies meaning' (1985: 37), the corporeality of the actor is integral to the construction of the role and this bodily dimension will be read in certain culturally constructed ways. But the actor is also a cumulative cultural product made up of the sum of previous performances: film actors carry with them a perfectly preserved celluloid past that can be exploited in the present-making it essential that we pay attention to the meanings encoded by popular, recognisable screen performers.

\section{Everyman in transition: reading John Mills}

In 1958, while no longer at the peak of his box-office appeal, John Mills was undoubtedly both a popular and recognisable figure, and he is perhaps the most obvious visual point of connection between In Which We Serve and Dunkirk. The first film effectively made Mills a star, while the second represents the deployment of his established screen persona for a set of practical and ideological purposes: he was both a reliable box-office draw and a symbol of reassurance who could serve as a shorthand for a set of national virtues which Dunkirk has neither the time nor the inclination to spell out. In other words, there is no need actually to show examples of humour, resilience, pluck, loyalty, duty or whatever if a director can cut to the chase by casting John Mills, as a brief account of his career will demonstrate.

Jeffrey Richards has observed that stars need to be "both ordinary for the purposes of identification and extraordinary for the purposes of admiration' (1984: 156), but Mills' stardom resides in his capacity to project an 'extraordinary ordinariness'. Mills had a brief glimpse of 


\section{Gill Plain}

screen stardom early in his career when he starred in the substantial, high-budget British feature Brown on Resolution (1935). Adapted from a C. S. Forester novel, the film tells the story of a heroic working-class sailor Albert Brown (Mills), who dies saving his ship during the First World War. The film was a success, but Mills was unable immediately to capitalise on this, not least because of the difficulties faced by the British film industry as the decade progressed. He returned to the stage but, nonetheless, this was a defining role, and his performance can be seen to have established him as an 'unwaved flag' of British national identity, a signifier of working-class loyalty and duty which would be reactivated by his casting in In Which We Serve (Billig 1995: 38; Plain 2006: 41-5, 50-4). Coward's film was typical of the war years in that it emphasised the heroic virtues of the group rather than of the individual: documentary realism promoted the nation as 'star', encouraging the audience to recognise and admire itself on the screen. Within this framework, though, Mills excelled as Shorty Blake, managing to be distinctive within the parameters of the composite heroic body represented by the ship and her crew. In Which We Serve made him an instantly recognisable figure, and was followed by leading roles in other national ensemble dramas: William Wilberforce in The Young Mr Pitt (1942), Commander Taylor in We Dive at Dawn (1943), Billy Mitchell, the boy next door, in This Happy Breed (1944) and Pilot Officer Penrose in The Way to the Stars (1945). As the list indicates, directors were happy to cast Mills across the spectrum of working- and middle-class possibility.

Mills' popularity was at its height in the late 1940s, and by this point he had come to signify a very particular model of national masculinity. He had become, and was frequently described as, an 'English Everyman':

John Mills, perhaps more than any other actor in British films, is able to portray the average young man-in-the-street on the screen. He has a real sympathetic quality, an authenticity which makes him down-toearth, ordinary and likeable. When one critic said of his performance that he was 'everybody's son, everybody's young man,' he pointed to a truth which is a further indication of why Mills is among the most popular of English actors. He is as British as actors like Spencer Tracy and James Cagney are American, his acting is natural and unforced, his attractive personality possesses the appeal of seeming to combine all that is best in our national character. (Noble 1947)

I have already suggested that actors are cumulative cultural products made up of the sum of their previous performances, and the 
cumulative effect of Mills' screen performances in this period was the creation of a screen persona encoding a set of qualities read as archetypally English, although in the above quotation Noble employs the terms 'British' and 'English' as if they were synonymous. Mills' youthful open face, his big eyes and his long feminine lashes contributed to his being read as the embodiment of innocence, honesty, sincerity and trustworthiness. The emphasis placed by Noble on the 'natural' quality of his acting similarly works to link him to qualities perceived to be national. In the landscape of national stereotypes, the English are an understated nation - being English does not need or find explicit articulation, and the ideal Englishman is a man of few words and contained emotions. By extension, therefore, an 'English' actor must of necessity seem inarticulate, undemonstrative and sexually restrained.

Another major factor in establishing Mills' status as an Everyman was his lack of height. The class mutability evident from his roles and performances was unusual for the $1940 \mathrm{~s}$, and made possible only because the combination of physical slightness, an eminently trustworthy face and an understated performance style made him an ideal choice for rendering potentially threatening figures safe. No one watching In Which We Serve could mistake Shorty Blake's humour for insubordination, and similarly his wartime officers are low-key, almost vulnerable, figures. So Mills in the 1940s was very much in tune with the nation's propaganda requirements. He represented the masculinity of the underdog, just as Britain in the 1940s had an investment in presenting itself as the underdog-a plucky little island standing alone against the great dictators.

This gives a flavour of the cultural meanings attached to Mills in the late 1940s, although the value attributed to these meanings was far from stable. As the 1940s gave way to the 1950s, trust, sincerity and dutifulness would prove less and less attractive at the box office, and, after Mills' starring role in 1948's Scott of the Antarctic, the meaning of his screen persona also began to change (although, once again, we have Mills starring in a film in which total disaster is reinscribed as a moral victory). In Scott, the actor described by Andrew Spicer as the ideal of 'democratic ordinariness' (2001: 10) was cast as the imperial hero-an earlier and, by 1945, a residual, version of national masculinity. ${ }^{12}$ There was a considerable amount of nostalgia invested in this retelling of the Scott story-nostalgia both for the recent homosocial camaraderie of wartime and for an older, more certain formation of national identity - and Mills' admirably repressed and authoritarian performance foreshadowed his later casting as the 
clipped and confident officer hero in films such as Above Us the Waves (1955) and The Colditz Story (1955). Although these films, both released in 1955, draw on the performance characteristics exhibited by Mills in the 1940s, they are not about democracy, ordinariness and vulnerability. Rather they represent the beginning of a fabulising process in which the myth of the 'finest hour' takes physical form on celluloid. These films encode a 'nostalgic virility' which flies in the face of the social and political changes taking place in the 1950s, presenting a range of individualistic, officer-class, military heroes who go about the business of winning the war without the slightest trace of doubt or anxiety. ${ }^{13}$ In these films, Britain is still great, the Empire is still intact and English masculinity is fixed and secure, if nonetheless incapable of articulation (Plain 2006: 141-2).

But what happens to a performance, and the ideas which it encodes, in the process of repetition? The trajectory outlined above suggests a process of concretisation, as innovation becomes the norm before collapsing into cliché. But cliché is also a state of exposure: it is immediately read as flawed and inadequate, and it reminds us that the repeated iteration of norms will ultimately expose their instability. In the performance of British masculinity, then, understatement becomes stiff upper lip, becomes repression, becomes breakdown. Or in cinematic terms, The Way to the Stars begets Above Us the Waves begets Ice Cold in Alex (1958) begets Tunes of Glory (1961). What, then, is going on when John Mills is cast as Tubby Binns in Dunkirk?

There is no doubt that, in casting Mills, Norman and Balcon were investing in a known commodity. But how stable was the Mills product in 1958? Although he had continued to represent the nation at war throughout the 1950s, he had done so as an officer rather than as an enlisted man. The nostalgic virility films, unlike many of his actual wartime performances, were officer-class roles, and in the ten years preceding Dunkirk, Mills' appearances in working-class roles had been confined largely to cameos, supporting roles or comedy: Barratt the handyman in The Rocking Horse Winner (1949), the title character of The History or Mr Polly (1949), Willie Mossop in David Lean's Hobson's Choice (1954), the down-at-heel detective Albert Parks in The End of the Affair (1955) and Puncher Roberts in The Baby and the Battleship (1956). If Shorty Blake's status as a protagonist rather than as comic relief had represented an innovation in British cinema, it is hard not to see this roll call of comic characters as at best residual and at worst regressive. But it might also have something to do with age. Mills was very slow to manifest the signs of ageing: he was 37 when he played the 21 -year-old Pip in Lean's Great Expectations (1946), and his face and body remained 
remarkably youthful throughout the early 1950s. But by Dunkirk he was approaching 50 and the lines were starting to show, which is a factor that limits the parameters of his working-class performances. Although the Second World War had opened up a space for the working-class hero in British cinema, as in, for example, the comedy thriller Waterloo Road (1945), it was undoubtedly a young man's space. Within the class landscape of the 1950s, age connoted authority and in representational terms remained the preserve of the middle or upper classes. Working-class heroes occupied subordinate positions, while the older working-class man slid inexorably back towards comic relief, ${ }^{14}$ with the result that, once Mills showed signs of ageing, his capacity to represent working-class heroes was circumscribed by the cultural constraints of 1950s class assumptions. Inevitably then, as he ages, Mills is cast less often in working-class roles and begins an inexorable transition towards the embodiment of authority.

As the 1950s progressed, then, the combined forces of age and cultural myth-making brought about a polarisation within Mills' screen persona. With the concretisation of his officer-class roles there came a parallel transition in his working-class roles from drama to comedy. And this bifurcation of his Everyman persona inevitably has an impact on his performance in Dunkirk, where for the first time in over ten years he is required to play a working-class soldier hero.

\section{Textual tensions: reading Dunkirk's conflicting narratives}

There are a number of factors which might account for Dunkirk's failure to capture the public or the critical imagination - not least of which is the fact that it cannot be read as a straightforward example of the war film. Rather, it is a generic hybrid which, in its failure to conform to one particular pattern of film-making, exposes the anxieties surrounding class and masculinity discussed in the previous section. In its early scenes, Dunkirk plays the war for comedy, drawing extensively on Mills' capacity to play the bewildered innocent, a skill refined in his performance as Willie Mossop in Hobson's Choice. The jokes are old and familiar, mobilising the comic cliché of the British abroad to make a spectacle of difference. In other words, Dunkirk's rich vein of humour depends upon the incomprehensibility of women and foreigners. In a typical example, as the comedy working-class soldiers begin their search for the right way home, their reluctant leader Tubby is forced to ask a column of refugees for directions: 'Pardon Monsewer', he asks, 'ou est Anglais?' Not surprisingly, Tubby receives no answer beyond an 


\section{Gill Plain}

expressive Gallic shrug, leading him to conclude: 'Dead stupid. Don't even understand their own language.' Mills' blank-face mask of dimwitted bemusement is ruffled a moment later when, after chivalrously rushing to assist a struggling (but beautiful) refugee, Tubby receives a resounding slap around the face. Confronted by the mystery of woman, Tubby's resemblance to Willie Mossop, or even to Stan Laurel, grows apace-but within moments of the encounter, the comedy of the sexes is ruptured by the more pressing narrative of war as Stukas strafe the column of refugees. The transition is uncomfortable, but it is not entirely surprising that a war film should have a comic dimension. Christine Geraghty (2000) has observed that the war film and the comedy were the two most popular genres of the 1950s, and films such as the Boultings' Private's Progress (1956) made very successful comedy out of the war. But the comedy in Dunkirk is not in the satirical vein of the Boultings, nor is it typical of the anti-authority banter and cynical commentary that crops up in films such as Above Us the Waves. Rather it is directed at, and is at the expense of, Tubby Binns, making fun of the man who is supposed to be leading the soldiers and exposing him as dim-witted and unimaginative. Given that Geraghty also notes the trend in war films towards the restoration of the individual hero, and that Tubby will indeed be required to lead his men effectively, his early presentation as Willie Mossop abroad inevitably suggests an uncertainty within the film about how to approach its subject matter, and indeed about what that subject matter might be.

This uncertainty is also evident in Dunkirk's approach to the war: as was noted earlier the film is torn between the demands of the generic war film of the 1950s and a more highbrow memorialising of events. Christine Geraghty describes the generic war adventure of the 1950 s as being characterised by an appeal to truth, a focus on a group of disparate men who must undertake a dangerous mission, an episodic narrative combining 'action and repose... comedy and tragedy', conflict within the group and a form of learning process (2000: 178). Within these parameters we could describe Dunkirk as Tubby Binns' journey from wise-cracking buffoon to competent commander of his tiny company. Yet set alongside this generic adventure is a far more ambitious historical narrative marked by extensive documentary montages which use maps, newspapers and original newsreel footage to tell the political and military story of the retreat. The film bears witness to the catastrophe of Dunkirk, acknowledging the mistakes, testifying to the courage and resilience of the armed services and struggling to present absolutely everybody who was involved. But, as Sue Harper and Vincent Porter have observed, 


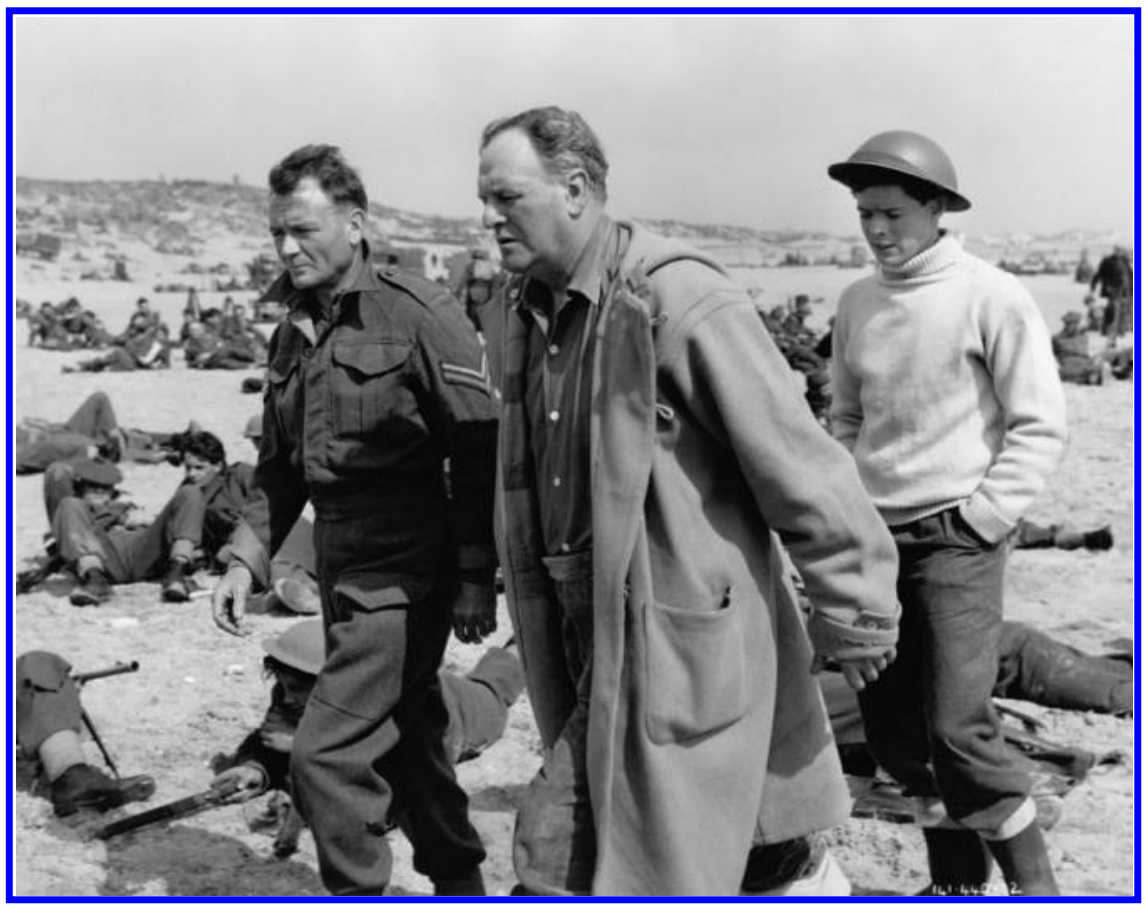

Fig. 1. Educating the workers: Tubby Binns (John Mills) and Charles Foreman (Bernard Lee).

in its drive for verisimilitude, Dunkirk overlooks the importance of emotional engagement:

What is really notable about Dunkirk is not its 'realism' but its emotionally frozen quality. It looks big, but it has a fatal inattention to emotional detail. Even war films have to have an emotional climax and focus, and it seems as though the sheer logistical problems involved in Dunkirk overly preoccupied the Ealing personnel. (2003: 70)

This suggestion that insight and character are sacrificed to spectacle raises the question of what exactly constitutes the climax of Dunkirk? In my earlier brief summary of the narrative, I suggested that its dramatic crux could arguably be seen as the encounter between Tubby and Foreman on the beach (Figure 1). This is the point at which the two stories - civilian and military-converge and the leading actors finally encounter each other. It is a welcome respite from the spectacular, and one of the few points within the film where the disparate elements of the drama seem to coalesce. It is, however, far from emotionally rewarding. For the duration of their encounter, whether they are 
walking together along the beach or sheltering from bombardment among the dunes, Foreman lectures Tubby, as teacher to pupil, about the causes and potential consequences of the Second World War:

Tubby: What happened? What caused all this?

Foreman: Stupidity. Everybody saying that war was so damnable it couldn't happen again, shoving our heads in the sand like a lot of ostriches. But the Germans didn't think that way. To them, war meant guns or butter. They chose guns. We chose butter. No, you can't blame the army. They had what we gave them. Last war weapons, last war methods. This is the result.

Tubby: What happens now? After this?

Foreman: If we're lucky, we'll get another chance. Heaven knows we don't deserve it. Get the best men in the right jobs.

Tubby: Do you think we've made a start? With old Churchill, I mean?

Foreman: Yes. Yes, I think we've made a start.

Given the scale of the drama, and the jeopardy involved in the evacuation of the beaches, this might seem a strange choice of climax, but it is, I believe, congruent both with Harper and Porter's observation that 'individual feelings were not Balcon's forte' (2003: 70) and with a reading of the film which ultimately places it not in the war genre but in that of the 1950s social problem film.

Harper and Porter describe the cinema of the 1950s as 'an anxious cinema, which worried away at the new social and sexual boundaries' (2003: 272) and, by the end of the decade, screens were swamped with realist narratives tackling topical social concerns ranging from youth culture and delinquency (Cosh Boy (1953), Violent Playground (1957)) to homosexuality (Victim (1961)) and racial prejudice (Sapphire (1959)). In Sex, Class and Realism, John Hill argues that the social problem film sought to maintain the status quo by providing narratives of reassurance which reintegrated 'troublesome elements' into the community (1986: 124-5). These films aimed to achieve consensus by situating new developments within safe and familiar frameworks, and key to this process was a discourse of middle-class male rationality which could impose order on troublesome emotions and give authority to a particular ideological position. In the character of Charles Foreman, Dunkirk acquires its very own voice of middle-class male rationality. With the luxury of hindsight, the film orders the emotive chaos of Dunkirk through his reassuring assertion that Britain will 
get it right next time. Throughout the film he condemns the stupidity of others and mediates the spectator's experience through his judgemental commentary, responding, for example, to Holden's selfishness with a cry of: 'I don't know. Fools at the top, fools at the bottom - there are times when I don't think we ought to win this war.'

And this is why the trajectory of the film leads us to Foreman's lecture on the beach. The problems of characterisation noted earlier ensure that the climax cannot be driven by personal development or revelation. With the exception of Mike, Tubby's group of soldiers are largely indistinguishable from each other. While the successful group hero of the war years was a heterogeneous body, markedly diverse in background and personality, in Dunkirk no time is spent giving substance to the soldiers or exploring their relationships. Consequently their scrapes and skirmishes have limited emotional impact, and Tubby's emergence as a leader is, to say the least, perfunctory. Indeed, he never seems to invest his leadership with any personal qualities and, when the men mutiny, his response is simply to say 'you can't buck the army'. This is not, then, a workingclass leader emerging from the cocoon of ignorance-rather it is a $\operatorname{cog}$ in the machine of the army performing a necessary role. And this is reinforced by the very temporary nature of Tubby's assumption of authority. The final shot of Dunkirk does not witness the postwar-or even the wartime-enablement of the working-class soldier, empowered by the initiative and agency which he has exhibited in battle; rather, it reminds us that a more significant film of 1958 was Carry On Sergeant. The film ends with Tubby and Mike being put through their paces on the drill square, their faces comically expressing the squaddie's customary resistance to authority. ${ }^{15}$ Tubby Binns is back where he belongs - in the ranks, part of a faceless, subordinate mass. His role was not to lead but to meet the appropriately named Foreman and feed him the questions which will enable the middle-class journalist to offer his verdict on the history of Dunkirk. ${ }^{16}$

Further evidence of the film's social-problem tendencies comes from its representation of women. Andrew Clay, writing about British crime films in the $1950 \mathrm{~s}$, observes that a 'crisis in masculinity' is evident in cinema's preoccupation with a 'loss of war-time agency and an anxiety about the status of the post-war woman' (1999: 52), and indeed the 1950s are packed with films which blame women for the ills of both men and of society as a whole. The working woman, the 'bad' woman, the sexual woman, even the domestic woman was a convenient scapegoat for the problems of postwar readjustment and the recognition that Britain remained at heart a class-bound and 


\section{Gill Plain}

conservative culture. Dunkirk conforms entirely to this pattern. Women appear in scarcely more than three scenes, but this nonetheless allows ample time for them to be depicted as needy, selfish, unable to see beyond the horizon of the domestic, narrow-minded, childish and wrong. The most extreme example is provided by Holden's wife Grace, who behaves like a spoilt child and absolutely refuses to acknowledge the demands or the realities of war. After proving herself incapable of fitting a gas mask onto her baby, she petulantly announces to her husband: 'I'll never be able to do it. I couldn't. You'll have to be here... promise me you'll never go away. Never leave baby and me.' Ironically, Dunkirk's representation of women transcends class boundaries. Working-, middle- and upper-middle-class women are all revealed as naive inhabitants of an exclusively private sphere. While Grace Holden demonstrates women's inability to see beyond personal relationships, the working-class women in Holden's factory give a master class in political irresponsibility. Still clinging to the logic of appeasement, they are taken in by the words of Lord Haw-Haw, they believe that Germany does not want war and they are sure that it will all be over by Christmas. Meanwhile, at the other end of the class spectrum, even Foreman's seemingly intelligent and emotionally restrained wife cannot quite let go of domestic priorities, repeatedly asking for reassurance that her husband will be back from war in time to visit his son's school. ${ }^{17}$

So what can an examination of Dunkirk's production and of the finished film tell us about working-class representation in the 1950s? In the territory of the popular middle-brow, beyond the radical emergence of the 'angry young man', working-class agency is in crisis, with the result that Dunkirk presents the viewer with a curious hybrid of Shorty Blake and Willie Mossop, overlaid by a touch of the tough, world-weary cynicism integral to Mills' roles in films such as Town on Trial (1957) and Tiger Bay (1959). It is undoubtedly, then, an unstable repetition of Mills' career-defining performance of workingclass masculinity, but this instability reveals not resistance to the dutiful masculinity embodied by Shorty but, rather, a concretisation of this subordinate status. By making Tubby Binns more stupid than Shorty Blake, by making a running joke out of his resistance to his stripes and the authority they embody, and by making him the passive subject of Charles Foreman's workers' education programme, Dunkirk reveals its deep-rooted anxieties about the changing world of the late 1950s. Christine Geraghty argues that, "like the comedies [of the 1950s], the war films take class as the basis of their organisation and turn away from the notion of a classless society' (2000: 195). The contemporary 
prejudices of Dunkirk make a significant contribution to its problems as both a war film and a tribute, and the distance between Tubby Binns and Shorty Blake ironically tells us that -in spite of the decline of deference-representing the working classes in mainstream British cinema became harder rather than easier in the aftermath of the Second World War.

\section{Notes}

1. Kenneth Tynan, Memo to Michael Balcon, 8 January 1957 (BFI, Sir Michael Balcon Special Collection, Item no. I/146b).

2. Michael Balcon, Notes on draft script for Dunkirk, 7 January 1957 (BFI, Sir Michael Balcon Special Collection, Item no. I/146b).

3. Letter Michael Balcon to David Divine, 26 November 1956 (BFI, Michael Balcon Special Collection, Item no. I/146).

4. This is a curious absence which stretches across autobiography, memoir and academic criticism. The film is hardly mentioned in John Mills' autobiography (2001: 331, 418), while in his memoir of 1969, Michael Balcon notes only that it was 'perhaps the largest-scale film with which I had ever been connected' (1969: 188). Among the critics, Robert Murphy pays more attention than most, noting the film's conformity to a late-1950s pattern in which 'fictionalised characters participate in real events' (2000: 249). He also notes the relationship between Tubby Binns and Shorty Blake (ibid., 208).

5. The title Dunkirk was first registered by London Films, while Romulus also considered a film on the subject, based on a script by Richard Vernon and David Divine. It was Divine's contribution to both the Ealing script and that owned by Leontine Entertainments Ltd which resulted in screenplay alterations and a legal debate which rumbled on until August 1957. The film went into production in April 1957 and Jack Hawkins pulled out at the beginning of May 1957.

6. The phrase comes from R. C. Sherriff, who claimed that the story of Dunkirk belonged to the 'National Trust' and, as such, the film-making process was under an obligation of sincerity and straightforwardness (BFI, Sir Michael Balcon Special Collection, Item no. I/146a).

7. BFI, Sir Michael Balcon Special Collection, Item no. I/146g, 22 April 1958.

8. Sonya Rose describes the legacy of the Second World War as a nation paradoxically united and divided around the concept of class. 'If the nation was one people', she argues, 'it was certainly a people who saw themselves as differentiated by social class' (2003: 67), and her reading of McKibbin (1998) leads her to conclude that Britain was 'a country in which those who had authority in 1951 were of the same social origins and social position as those who held it in 1918' (2003: 68).

9. BFI, Sir Michael Balcon Special Collection, Item no. I/146b.

10. BFI, Sir Michael Balcon Special Collection, Item no. I/146b.

11. For a full discussion of the process through which actors in general, and Mills in particular, acquire cumulative cultural meaning, see Plain (2006: 7-17).

12. This is not to suggest the disappearance of the imperial hero from popular film narratives. However, manifestations of this type look back to constructions of masculinity rooted in Victorian, Edwardian and interwar ideas regarding nation, duty, class and belonging. The emergence in the Second World War of a plausible working-class hero, however, was the precursor to a series of paradigm shifts in 


\section{Gill Plain}

masculinity, customarily associated with the 'angry young man'. By the late 1940s, imperial heroes could still be enjoyed, but they were not recognisably 'modern'.

13. This is the rewriting of history to which Rattigan refers (1994: 150).

14. In Morning Departure, for example, Higgins (James Hayter), the older workingclass figure, comes to occupy a feminised position next to the patriarchal authority of Mills' commanding officer. It is worth noting that Mills had not had a full-scale outing as a working-class hero since 1945's Waterloo Road. Town on Trial (1957) is an anomaly and difficult to place in relation to class. Mills' character, the policeman Mike Halloran, is undoubtedly from a working-class background, but his status as a detective neutralises him, perhaps because of the generic, self-consciously 'American', tough-guy style of the film. That the Dunkirk producers had some sense of this representational problem is evident from another of Kenneth Tynan's preproduction memos, in which he compares Binns to a 'traditional Jimmy Hayter type' (BFI, Sir Michael Balcon Special Collection, Item no. I/146a, 20 February 1956).

15. This ending also prompted criticism at the time. Cecil Day-Lewis, charged with writing the epilogue for the film, worried that the return to the drill square was banal and bathetic, working against the rhetorical impact of his words (Letter to Leslie Norman, 23 December 1957; BFI, Sir Michael Balcon Special Collection, Item no. I/146f).

16. Unfortunately for Dunkirk's ability to bear witness to the horror of the withdrawal, Foreman's presence also has a distancing effect. By hinting at the big picture, the character of Foreman diffuses the tension of the immediate picture: men trapped, in retreat, suffering a monumental defeat. There are reasons for such an approach to the story. The triumph over adversity narrative offers significant reassurance: things looked bad at Dunkirk, but strength of character saw the nation through. That such a narrative should appear in a post-Suez context is not surprising. Dunkirk counsels faith in authority at the same time as it acknowledges its flaws: in 1958 , in a changing, disturbing new world, the spectator is reassured that Britain has been through worse and lived to fight another day. But however reassuring this message, the narrative tension pays a price for the comforts of nostalgia.

17. Leslie Norman's notes on the Sherriff screenplay observe the absence of women and insist that the women of the period should be 'symbolised' in the drama. This speaks both to the desire for inclusivity and the belief that women characters would facilitate emotional involvement with the characters. The end product, however, does little for women either of the 1940s or the 1950s, 19 March 1956 (BFI, Michael Balcon Special Collection, Item no. I/146a).

\section{References}

Aldgate, Anthony and Jeffrey, Richards (1994), Britain Can Take It: The British Cinema in the Second World War, third edition, Edinburgh: Edinburgh University Press.

Balcon, Michael (1969), Michael Balcon Presents... A Lifetime of Films, London: Hutchinson.

Barr, Charles (1998), Ealing Studios, third edition, Berkeley, CA: University of California Press.

Billig, Michael (1995), Banal Nationalism, London: Sage.

Clay, Andrew (1999), 'Men, women and money: masculinity in crisis in the British professional crime film, 1946-1965', in Steve Chibnall and Robert Murphy (eds), British Crime Cinema, London: Routledge, pp. 51-65. 


\section{From Shorty Blake to Tubby Binns}

Geraghty, Christine (2000), British Cinema in the Fifties: Gender, Genre and the 'New Look', London: Routledge.

Harper, Sue and Porter, Vincent (2003), British Cinema of the 1950s: The Decline of Deference, Oxford: Oxford University Press.

Hill, John (1986), Sex, Class and Realism: British Cinema 1956-1963, London: BFI.

King, Barry (1985), 'Articulating stardom', in Screen, 26: 5, pp. 27-50.

McKibbin, Ross (1998), Classes and Cultures: England 1918-1951, Oxford: Oxford University Press.

Mills, John (2001), Up in The Clouds, Gentlemen Please, second edition, London: Orion. Murphy, Robert (2000), British Cinema and the Second World War, London: Continuum. Noble, Peter (1947), 'Profile of John Mills', Stage and Screen, Spring.

Plain, Gill (2006), John Mills and British Cinema: Masculinity, Identity and Nation, Edinburgh: Edinburgh University Press.

Priestley, J. B. (1940), Postscripts, London: Heinemann.

Rattigan, Neil (1994), 'The last gasp of the middle class: British war films of the 1950s', in Wheeler Winston Dixon (ed.), Re-Viewing British Cinema, 1900-1992, Albany, NY: State University of New York Press.

Richards, Jeffrey (1984), The Age of the Dream Palace: Cinema and Society in Britain, 1930-1939, London: Routledge \& Kegan Paul.

Rose, Sonya (2003), Which People's War? National Identity and Citizenship in Wartime Britain, 1939-1945, Oxford: Oxford University Press.

Spicer, Andrew (2001), Typical Men: The Representation of Masculinity in Popular British Cinema, London: I. B. Tauris.

Gill Plain is Professor of English Literature and Popular Culture at the University of St Andrews. She has research interests in war and representation, gender, national identity and crime fiction. Her publications include Women's Fiction of the Second World War (1996), Twentieth-Century Crime Fiction: Gender, Sexuality and the Body (2001) and John Mills and British Cinema: Masculinity, Identity and Nation (2006). She is currently working on a literary history of the 1940s. 